\title{
LEGAL AND POLICY FRAMEWORK FOR ECOSYSTEM-BASED ADAPTATION TO CLIMATE CHANGE IN MALAYSIA: A REFORM ORIENTED STUDY
}

\author{
By \\ Dr. Abdul Haseeb Ansari \\ Professor, Ahmad Ibrahim Faculty of Laws, IIUM, Malaysia \\ ahaseeb@iium.edu.my
}

\section{Prelude}

Rise of average global temperature and its global disastrous impacts, due to unusual weather conditions, are escalating despite greenhouse gases (GHGs) reduction commitments under the Kyoto Protocol, as the mitigation mechanisms alone cannot do away with the sufferance of the people on long-term basis. It has to be combined with adaptation (Klein, Huq, Denton, \& Downing, 2007). Adaptation to tenacious adverse impacts of climate change is crucial for alleviating the menace of the people. Adaptation within the context of UNFCCC is very restrictive and lacks detailed strategy. It is for this reason that mitigation measures combined with adaptation can best be practiced at regional, national and local level. (Koh and Lovleen, 2011; Sahraie, 2011, Othman, 2011). It has been said so in the Fourth Assessment Report of the IPCC, 2007. This is because although there are a number of strategies developed under its auspices, their implementation depends on a viable national adaptation plans and effective programmes of action within the Cancun Adaptation Framework and Nairobi Work Programme supported with encouraging transfer of environmentally sound technologies (ESTs), research support, financial support and support in capacity building. A successful programme at these levels depends on political will on the part of the state supported by all stakeholders, national and international, including people at the grass root level. All these have been well spelled out and discussed in the IPCC WGII AR5 entitled Climate Change 2014: Impacts, Adaptation and Vulnerability, released on 1 April 2014. (See infra)

The $5^{\text {th }}$ IPCC Report 'Assessing Impacts of Climate Change on Human Health, Settlements and Natural Resources', released on 30 March 2014, states that Asia is facing the brunt of climate change and will see severe stress on water resources and food-grains production. It warned that the worst is yet to come if no measures are taken to curb the ill effects of global warming. (Emphasis supplied by the author) Chapter 24 of the IPCC Working Group II of the Assessment Report of 2014 concludes that there is increase in warm days and higher temperature will lead to lower rice yield, which may result in water scarcity and changes in arid and semiarid areas, loss of mangroves and coral reefs, increase in mortality rate. The Report clearly emphasises on taking all possible measures for mitigation and ecosystem-based adaptation (EbA). The legal aspect of EbA outlines the responses to the impact of climate change, which can enhance adaptive capacity and reduce climate risk vulnerability. In fact, mitigation measures, adaptation practices and change in consumption patterns are three important tools for sustained living on the planet. Mitigation and consumption practice have to be adopted to do away with the sufferance of the people posed by climate change. For example, the April 2014 water crisis in the Klang Valley of Malaysia has prompted the government to resort to water rationing, which will instill among the people to know the importance of water and not to misuse or waste it, and to harvest rain water, which is broadly practiced in India. This may be resorted to in Sao Paulo, Brazil and other parts of the world facing water crisis. Actually, these measures are part of adaptation. Government had to adopt immediate mitigation measures by bringing water from Negri Sembilan to Selangor, to upgrade dams, and to improve water purification and supply system. For improving consumption patterns, governments does not have to spend money; whereas, for 
mitigation measure it will have to spend money and employ necessary technology. In short, it can be graphically depicted as:

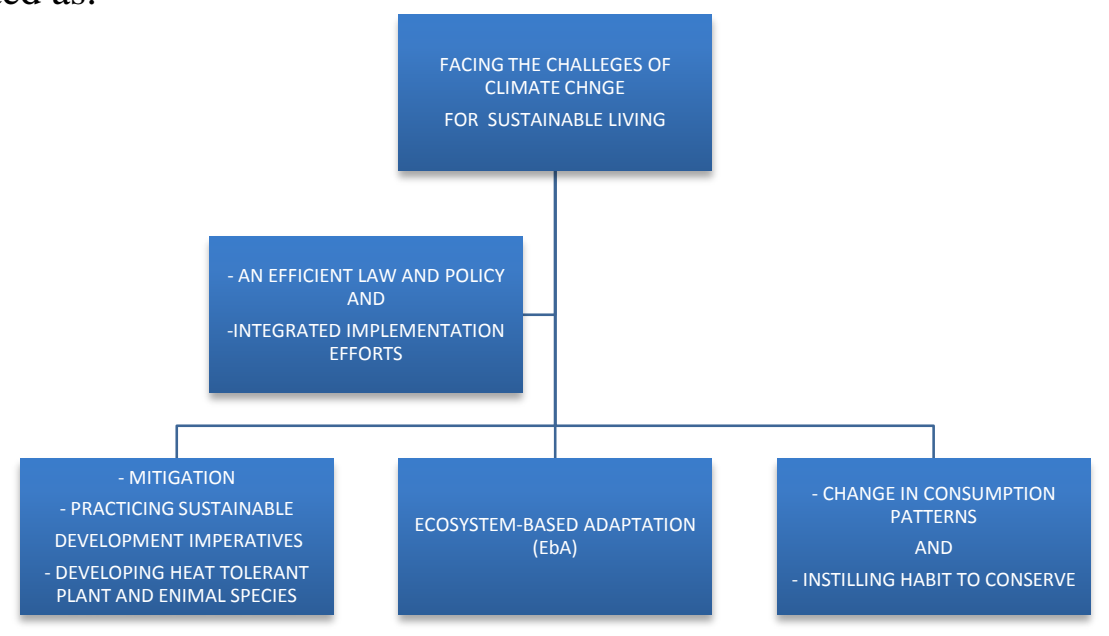

The Convention on Biological Diversity (CBD) defines EbA as: "the use of biodiversity and ecosystem services as part of an overall adaptation strategy to help people adapt to the adverse effects of climate change." The UNDP Draft Working Paper 3-11-2010 on "Ecosystems, Disasters and Climate Change" defines it as an integrated ecological approach that links ecosystems to disaster and climate risk management. EbA measures frequently complement disaster risk reduction objectives. EbA integrates the use of ecosystem services into an overall strategy to help people adapt the adverse impacts of climate change and reduce risk of climate-induced disasters. It includes the sustainable management, conservation and restoration of ecosystems to provide services that help people adapt to both current climate variability, and climate change. According to CBD, an ecosystem-based approach uses biodiversity and ecosystem services and generates socio-economic as well as ecological benefits. EbA-based approach, thus, entails an ecosystem adaptation approach that promotes activities, which address both human and biological aspects of the ecosystem. It relies on recovering and maintaining ecosystem services and the resilience of natural resources rather than on engineering and costly manmade infrastructure like sea walls, jetties, and levels. Ecosystem services are those aspects of ecosystems that are consumed or utilized to yield human wellbeing (Turner and Daily, 2008).

Climate change control approach is divided into two, 'hard' measures and 'soft' measures. 'Hard' measures involve high capital engineering and building of climate-friendly structures, which require high budgetary input. 'Soft' measures involve EbA, which is cost effective by maintaining existing natural ecosystem structures and improve ecosystem services (Huq, Renaud, \& Sebesvari, n.d.). EbA approaches have the potential to significantly increase the functionality of current adaptation practices and reduce the tension of 'hard' and 'soft' approach by following three major ways: a) valuing ecosystems and biodiversity in adaptation; b) promoting development in adaptation; and c) building long-term resilience with multiple socio-economic benefits (Huq et al., n.d.). According to the author there can be a fourth way: to develop heat tolerant plant and animal species, e.g. developing, especially by gene manipulation or crossbreeding, heat tolerant poultry based on the African nakedneck chickens and Brahman bread of cattle of India (Evan Halper; Fillippo Ferrario et. al). Developing intensity, by conserving, restoring and creating their new of coral reefs is also a good adaptation technique in view of the rise of the sea level, instead of building concrete walls, is a better choice, as they have tremendous capacity to dissipate the sea-current thrust (Ingham, Richard). Research should 
also be augmented to develop marine species that could change their eating habits and could protect their shells from acidification of the seawater. It will ensure all functions that a healthy ecosystem can render to the nature and the people depending on it (A. Colls, 2009; Boer \& Clarke, 2012; Pérez, Fernández, \& Gatti, 2010; Pramova, Locatelli, Brockhaus, \& Fohlmeister, 2012). It will then have a dynamic relationship between and among species as well as abiotic environmental interactions (Boer \& Clarke, 2012). EbA, in practice, varies depending on the peculiar environment and natural landscape. However, it involves a wide range of ecosystem management activities to increase resilience and reduce the vulnerability of people and the environment to climate change. According to IUCN (2009), EbA practices may include the following:

- Sustainable water management, where river basins, aquifers, flood plains, and their associated vegetation are managed to provide water storage and flood regulation services;

- Disaster risk reduction, where restoration of coastal habitats such as mangroves can be a particularly effective measure against storm-surges, saline intrusion and coastal erosion;

- Sustainable management of grasslands and rangelands, to enhance pastoral livelihoods and increase resilience to drought and flooding;

- Establishment of diverse agricultural systems, where using indigenous knowledge of specific crop and livestock varieties, maintaining genetic diversity of crops and livestock, and conserving diverse agricultural landscapes secures food provision in changing local climatic conditions;

- Strategic management of shrub lands and forests to limit the frequency and size of uncontrolled forest fires; and

- Establishing and effectively managing protected area systems to ensure the continued delivery of ecosystem services that increase resilience to climate change.

Malaysia is working under the suggested measures. Additional measures adopted by it are with respect to trans-boundary haze, which has become an annual occurrence in the region. EbA when applied to indigenous peoples' right it focuses on conserving biodiversity and the natural resources essential for the survival and livelihood of coastal and agricultural communities in Malaysia. Sustainable livelihood for rural people, who are highly dependent on natural marine and terrestrial resources in their habitat, can be achieved better and faster through a well-designed EbA. Many of these resources have international and national economic value, e.g. coral reefs, forests for timber, water, medicinal plants and habitat for animal species (Gatti, n.d.; Huq et al., n.d.; Pérez et al., 2010). In addition, continued development, population pressure account for widespread non-forest use of forests and nonsustainable land use practices, which exacerbate the vulnerability to extreme events relating to climate change. Ecosystems are easy and cheaper to be maintained, and often more effective than physical engineering structures, such as dykes or concrete walls because they are natural buffers for self-repair of the environment. EbA, therefore, offers a means of adaptation that is readily available to the rural poor; it can be readily integrated into community-based adaptation and addresses many of the concerns and priorities identified by the most vulnerable countries and people. The role of the local community in adaptation has been overwhelming. Huq et al., n.d. observed that irrespective of sectors, analysis showed that in case an EbA was implemented by the process which involved local communities proved to be very efficacious. But it must be acknowledged along with other aspects such as cost effectiveness, flexible management, self-contained building, and multiple geographic processes. Other role to be played by the local community is maintenance of ecosystem resources for enhanced resilience and regeneration. This has proven to be successful in maintaining the Tasek Bera wetlands, the first Malsysian Ramsar cite, of Malaysia by training the inhabitants about ecotourism 
(Ansari,

2012).

A community-based adaptation programme was launched by Green Coast in the tsunami-affected areas in Indonesia, Sri Lanka, India, Thailand, and Malaysia (A. Colls, 2009). Adopting a communityled approach, the Green Coast ${ }^{1}$ Programme seeks to improve local livelihoods via four main activities: (1) Coastal ecosystem rehabilitation; (2) Building environmentally sustainable livelihoods; (3) Developing village regulations to support environmental conservation efforts; and (4) Environmental education campaigns. The climate of Malaysia is tropical and humid. It is very much influenced by the mountainous topography and complex land-sea interactions. Malaysia's climate is a tropical climate with uniform temperature (ranging with maximum 33 degree centigrade and minimum 23 degree Celsius) with relatively high humidity. It is divided into 2 seasons, which are Southwest Monsoon, Northeast Monsoon and 2 shorter periods of Inter-monsoon seasons. It is geographically located just outside the "Pacific Rim of Fire" but has not recorded severe natural disasters such as earthquake, volcanic eruption and typhoon. Although Malaysia is spared from the threats of severe natural disasters and calamities; nonetheless, it is not spared from other disasters such as flood, man-made disaster, landslide and severe haze (Ministry of Natural Resources and Environment, NRE, 2007).

Climate change and its impacts are serious issues in the region as they are rightly predicted to cause disasters via unusual weather conditions which might have adverse impacts, including those that may also destabilize the life and livelihood of people particularly in rural communities who mainly survive on ecosystems services (Koh \& Lovleen, 2011; Othman, 2011; Ruhizal Roosli, Phil O'Keefe, 2013) The frequencies and scales of droughts due to scanty or no rain, floods due to unprecedented heavy rain and sedimentation, forest fire due to scanty or no rain causing haze conditions, rise of sea levels resulting into loss of territory, salination, desertification, loss of coral reefs and marine biodiversity are already causing unprecedented scourge to the people in the ASEAN region (Boer \& Clarke, 2012). Malaysia is not an exception to these. Its people are already suffering from water scarcity, deluge and haze. In past few years, Malaysia has experienced several extreme weather and climatic events, ranging from freak thunderstorms, monsoonal floods, man-made disasters, landslides, and severe hazes that have caused havoc in the country. Monsoonal floods are an annual occurrence, which varies in terms of severity, place and time of occurrences. The most recent flood, which occurred back in 2010 in Kedah and Perlis and in 3013 in Pahang, were among the worst flood ever experienced by the country. The total economic loss and the financial burden on the government were enormous. Flood poised the most significant hazard affecting 4.82 million people and causing damages amounting to RM915 million yearly. Other than flooding, the country also, from time to time, experiences some man-made disasters, which caused considerable damage to properties and loss of lives (3rd AIPA CAUCUS REPORT, 2011). Predictive climate modeling and development projections have been intensified to enable the country to adapt challenges of climate change vulnerability. At present, Malaysia is able to absorb climate change impacts, given its strong environmental management programmes, backed by stringent economic policies including effective poverty eradication and food production programs. However, it must be made clear that these efforts address only the 'environmental change threat' and not specifically the 'climate change threat' where in the long-term the impact scenario for Malaysia would generally diverge. Climate change can trigger national and international distributional conflicts in Malaysia, e.g. within its fisheries sector, and intensify problems already hard to manage in the region (Robert W. Solar, 2011). If emissions of greenhouse gases are not considerably alleviated by resorting to renewable energy sources, unusual whether conditions might aggravate the miseries, which will make adaption more challenging, and

\footnotetext{
${ }^{1}$ Green Coast is a coastal rehabilitation programme helping restore and manage damaged coastal ecosystems in Southeast funded by Oxfam Novib (Netherlands).
} 
Malaysia may not be an exception to it (John Roach, 3013; Robert W. Solar, 2011; See IPCC III Report 2014, released on 13 April 2014).

Policy framework on climate change adaptation in Malaysia includes: National Policy on Climate Change, Coral Triangle Initiative-CTI, Southeast Asia Disaster Prevention Research InstituteSEADPRI-UKM, Malaysia Action Plan for Disaster Risk Reduction-MyDRR, Initial National Communication (INC), and Second National Communication to the UNFCCC (NC2) (Annex-5 Decision Document on $\square$ : Climate Change Adaptation Working Group Report, 2012; Pereira, 2013; Robert W. Solar, 2011). The policy and framework are implemented in conjunction with ministerial adaptation awareness programmes together by MOSTI, MNRE, NAHRIM, MKN, etc. Seven sectors have been identified in the Vulnerability and Assessment of updates contained in the NC2, which is an update of the (INC) assessment in identifying potential impacts. The sectors are: Water Resources, Agriculture, Biodiversity, Forestry, Coastal and Marine Resources, Energy, and Public Health (NRE, 2007). Some of the sectors mainly focused on mitigation and not adaptation; therefore, this research will shed light on sectors, which are related to ecosystem adaptation to climate change in Malaysia.

This paper first sheds some light on the conceptual aspects of adaptation and on the fact that it goes hand-in-hand with mitigation. It then discusses the legal and policy framework adopted by the Malaysian government towards adaptation to climate change in the context of the natural ecosystem. It outlines the known impacts of climate change within and around the Malaysian peninsula and vulnerability of the ecosystem, which serves the basic needs of the rural people while also maintaining the natural environment. Ecosystem- based adaptation can serve as a cost-effective method to reduce risk to climate change impacts and can provide sustainable livelihood for local people with the inherent natural self-regenerating ecosystem mechanism.

\section{Adaptation and Mitigation: Meaning and Scope}

\section{a. Adaptation}

Adaptation is the adjustments of natural or human system in response to actual or expected stimuli, or its effects to moderate the harm or exploit beneficial opportunities (IPCC, 2007). It is a process of adjustment to actual or expected climate and its effect. In human systems, adaptation seeks to moderate or avoid harm or exploit beneficial opportunities (IPCC: WGII AR5, 2014). Thus, the term adaptation is used in climate change realm to mean adjustments in a natural system's behaviour and characteristics that enhance the ability to cope with external stresses (drought, Cyclone, Tornado, flood, tsunami, etc.). It has appropriately been defined by the European Commission as: "Adaptation means anticipating the adverse effects of climate change and taking appropriate action to prevent or minimise the damage they can cause, or taking advantage of opportunities that may arise." For example: using scarce water resources more efficiently; adopting building codes to future climate conditions and extreme weather events; building flood defences and raising the levels of dykes; developing drought-tolerant crops; choosing tree species and forestry practices less vulnerable to unusual heat, storms and fires; and setting aside land corridors to help species to migrate. ${ }^{2}$ The constant levels of hazard over time, adaptation will allow a system to reduce the risk associated with these hazards by reducing its social vulnerability. Faced with increased hazard, natural systems may maintain current levels of risk through an enhanced ecosystem-based adaptation (Brooks, 2003).

The UNFCCC includes several references to adaptation, but the term is not defined in the document. The Subsidiary Body for Scientific and Technological Advice addresses the scientific and technical aspects of adaptation and technology transfer, including the Nairobi work program on impacts,

\footnotetext{
${ }^{2}$ European Commission, "Adaptation to Climate Change", at: http://ec.europa.eu/clima/policies/adaptation/index en.htm (Accessed on 12 March 2014).
} 
vulnerability and adaptation to climate change. The Kyoto Protocol also requires that all parties to develop national (and regional) adaptation programs [Article 10(b)], but it does not discuss the issue of adaptation in detail. Nevertheless, adaptation has formed an integral element of the Bali Action Plan 2007 and the Copenhagen Accord 2009, as well as the mandate of the Ad Hoc Working Group on
Long-term
Cooperative
Action
(Koh\&Lovleen,
2011).

The Third Assessment Report of the IPCC (IPCC-TAR 2001) identified various types of adaptation, which can be distinguished from each other, they include: anticipatory and reactive adaptation; private and public adaptation; and autonomous and planned adaptation. Reactive measures are implemented in response to current climate variability and observed impacts; whereas, anticipatory measures are undertaken before impacts are observed to reduce exposure to future risks. The systemic and proactive approach of EbA contrasts with the interventionist and reactive nature of many existing adaptation proposals and plans that portray adaptation as a tool of last resort in dealing with the threat of an unpredictable climate. This reactive approach supports the prioritization of "...already existing strategies" and results in "end-of-the pipe" infrastructural, land use planning and technological interventions that are responsive to only a narrow range of outcomes and probabilities. Although until recently, efforts to reduce current impacts of climate change have primarily focused on mitigating the accumulation of greenhouse gases in the atmosphere, adaptation is recognized as the fundamental (Klein et al., 2007; Koh \& Lovleen, 2011; Wertz-Kanounnikoff, Locatelli, Wunder, \& Brockhaus, 2011).

The evolution of climate change adaptation policy and legal framework has shifted from the initial top-down analyses of impacts assessment and vulnerability assessments to bottom-up approach through various National Adaptation Planning Programmes of Action or NAPAs ${ }^{3}$ (Nelson, Lamboll, \& Arendse, 2008). Prior to NAPAs, there was clear policy direction towards mitigation under the mechanisms in the Kyoto Protocol.

\begin{tabular}{|l|l|l|}
\hline Phase & Main Focus & Approach \\
\hline Phase1: & Climate Change Impacts & Top down (analytical) \\
\hline Phase 2: & Vulnerability & Top down (analytical) \\
\hline Phase 3: & $\begin{array}{l}\text { Mitigation Planning with less } \\
\text { focus on Adaptation (Regional } \\
\text { instruments, NAPAs, etc.) }\end{array}$ & $\begin{array}{l}\text { Top down \& bottom up } \\
\text { (planning) }\end{array}$ \\
\hline $\begin{array}{l}\text { Phase 4: National and community } \\
\text { adaptation initiatives }\end{array}$ & $\begin{array}{l}\text { Development of adaptation } \\
\text { policies, guideline }\end{array}$ & \\
\hline
\end{tabular}

Source: Adapted from (Nelson et al., 2008) with additional information by the author.

Experts are not agreed on the framework for adaptation to climate change (Lim, Spanger-siegfried, Burton, Malone, \& Huq, n.d.; Nelson et al., 2008). They have suggested some basic principles on which a viable climate change adaptation action plan can be developed. The suggestions include the following:

\footnotetext{
${ }^{3}$ For more information on NAPAs, see at: http://unfccc.int/adaptation/napas/items/2679.php (accessed on 12 November 2013)
} 
- $\quad$ Adaptation to short-term climate variability and extreme events is included as a basis for reducing vulnerability to longer-term climate change.

- $\quad$ Adaptation policy and measures are assessed in a developmental context.

- $\quad$ Adaptation occurs at different levels in the society, including the local level.

- $\quad$ Both strategy and the process by which adaptation is implemented are equally important.

\section{b. Relationship between Adaptation and Mitigation}

The IPCC-TAR, 2001 used the following definition of climate change Mitigation as: $A n$ anthropogenic intervention to reduce the sources or enhance the sinks of greenhouse gases. A combined effort of adaptation and mitigation is necessary for effective climate policy aimed at reducing the risks to natural and human systems (Klein et al., 2007). This involves a portfolio of diverse adaptation and mitigation actions at all levels of policy-making. Overtime, mitigation efforts on the international scene have proven to be inadequate to control the growing threat of climate change impact.

The inter-relationship between adaptation and mitigation is so overwhelming since without mitigation, a magnitude of climate change is likely to be reached that makes adaptation impossible for some natural ecosystems, while for most human systems it would involve very high social and economic costs. It is often argued that adaptation is inferior to mitigation since, it is claimed, the former is unsuitable for dealing with the impacts of climate change on natural systems (IPCC 2001).

Essential points of differences between mitigation and adaptation are: for mitigation to be effective, it requires the participation of major greenhouse-gas emitters globally; whereas, most adaptation takes place from sufferers from local to national levels. The climate benefits of mitigation are global, while its costs and ancillary benefits arise locally. In most cases, both the costs and benefits of adaptation accrue both locally and nationally. In addition, mitigation is primarily driven by international agreements and ensuing national public policies, possibly supplemented by unilateral and voluntary actions; whereas, most adaptation efforts involve private actions of affected entities, public arrangements of impacted communities, and national policies (Klein et al., 2007).

According to Goklany (2005), it is understood that mitigation reduces all impacts (positive and negative) of climate change and thus decreases the adaptation challenges; whereas, adaptation is selective; it can take advantage of positive impacts and reduce negative ones.

IPCC 2007 identified four models for inter-relationship between adaptation and mitigation (Klein et al., 2007) that can take several forms:

- Adaptation actions that have consequences for mitigation,

- Mitigation actions that have consequences for adaptation,

- Decisions that include trade-offs or synergies between adaptation and mitigation, and

- Processes that have consequences for both adaptation and mitigation. 
The working relationship between the whole scenario of emission impacts and socioeconomic and environmental processes with adaptation and mitigation can be best understood from the diagram below.

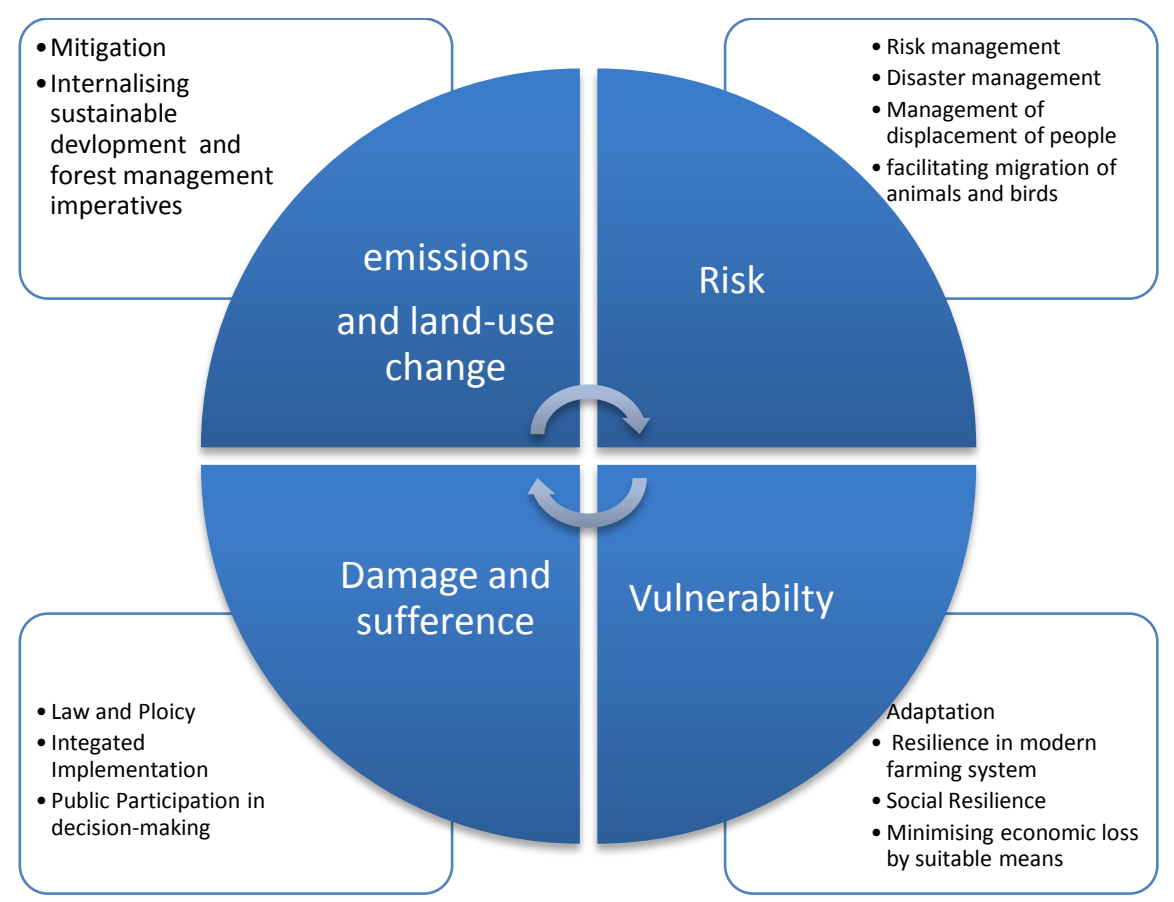

Prepared on the basis of the IPCC WGII AR5 entitled Climate Change 2014: Impacts, Adaptation and Vulnerability, released on 1 April 2014.

Mitigation, sustainable development and sustainable management of forests, adaptation and risk management require a competent law and policy implemented in an integrated manner, i.e., all relevant government departments and stakeholders must work together with an embedded essential factor to minimize all kinds of economic impacts on the people. Thus, policy and law should incorporate: an effective environmental conservation planning and land-use planning; reduction in the vulnerability of lifeline infrastructure and services, especially water and energy, e.g. resorting to conservation of water and energy, exploring other water sources, like looking for exploiting underground water, and moving water from rivers to lakes for domestic supply and irrigation, resorting to alternative and renewable energy sources; working for sustainable cities; developing means of indoor economic activities; working on heat resistant crops and trees; resilience in modern farming systems (Miguel A. Altieri et al, 2014). For an effective adaptation planning, all must work together to meet the challenges of global warming on forests, crops, biodiversity, resources on the ground, fresh waters resources, and marine resources. It is also necessary to effectively meet the challenges posed by contra factors, e.g. limited coordination among the relevant government departments; limited finance and trained personnel; lack of definite perception about risks; lack of technology; lack of monitoring and incompetence in research.

\section{c. Adaptive Capacity of the Malaysian Ecosystem}

Adaptive capacity is the ability of an ecosystem to adjust to climate change (including climate variability and extremes) to moderate potential damages, to take advantage of opportunities, and to 
cope with the consequences (IPCC, 2007). Factors that may affect adaptive capacity of a given ecosystem includes, existing mitigation measure, place, internal attributes of the population, place or system related vulnerability, sensitivity, and resilience (Nelson et al., 2008). The Malaysian ecosystem, being situated at the equator, has rich vegetation and other natural resources. It can sustain the situation even if there is no rain for weeks. However, its adaptive capacity is not so strong. If hot spell persists long, it suffers from forest fire resulting in haze conditions and shortage of water in inland watercourses, warrants mitigation, resulting in high vulnerability limited resilience on the part of the ecosystem and the people. An efficient adaptation programme, thus, has to be cost-effective and has to be the greatest value to the efforts made; emphasis must be given to characteristics of system vulnerability, such as resilience, critical thresholds. But coping ranges are highly dependent on the topography of a region or a nations (Adhikary, Ando, Anokhin, \& Cruz, n.d.). It is for these reasons that adaptation is increasingly becoming an important factor of the development agenda and planning, especially in developing countries, including Malaysia, and least developed countries as most of them are at high risk and vulnerable situation (Fankhauser, 2009).

It is for these reasons that now at the forefront are: scientific inquiries and policy negotiations. One of the main challenges in the current adaptation work is to understand and demonstrate how adaptation works and what the implications of adaptation for resilience are (Tschakert and Dietrich, 2010). This dynamic notion of adaptation allows promoting resilience of both ecosystems and human societies, beyond mere technological options mainly focused at building hard infrastructure and other similar measures but a synergy between mitigation and adaptation. Malaysian authorities are well aware of the probable implications of adaptation in order to have public facilities resilient.

\section{Environmental Governance in Malaysia}

\section{a. Sources of Malaysian Climate Change Regulations}

In Malaysia, there exist series of laws, which define the roles and responsibilities of various concerned agencies for specific action to combat climate change and its impacts. Among them, at the federal level are: the Land Conservation Act; the Environmental Quality Act; Town and Country Planning Act; Irrigation and Drainage Act; and Uniform Building Byelaw. The result of this is that climate change adaptation strategies and plans are embedded within the organization and functioning of governmental agencies at all levels and sectors.

EbA is highly linked to environmental and resource management legislation. For example, ecosystem resilience and ecosystem health is affected by legislation that regulates resource extraction and development, i.e. logging, fishing, environmental protection legislation (Baker-jones, Burton, Bell, \& Chang Seng, 2013). This link has been identified in Malaysia to justify the plethora of environmental legislation aimed at protecting the ecosystem and reduces vulnerability to climatic change impact.

An effective climate change adaptation framework must create a synergy among all stakeholders including the rural people, local government, state and federal government. Building adaptive capacity for the most vulnerable therefore requires a dual approach: first, a 'bottom-up', locally-inclusive approach to adaptation planning that is sensitive to the disaggregated nature of climate change vulnerability and the fault lines of social exclusion at the local level; and second, this local-level adaptation must be supported by higher-level institutions that enable access for poor and exclude groups to the assets and institutional system that will help them build adaptive capacity and act as the means of delivery for external resources to facilitate adaptation (Sterrett, 2011) 
In order to truly embed climate change adaptation into organisations and communities, it is essential that the risks and liabilities related to climate change have to be been identified, assessed and managed. This can only be achieved if decision-makers at all levels understand how climate change impacts will affect their decision making (Baker-jones et al., 2013).

\section{b. Regional framework for Ecosystem-based adaptation}

Southeast Asia is one of the most dynamic and fast growing regions in the world today. But with long coastlines, population and economic activity concentrated in coastal areas, reliance on agriculture in providing livelihoods for a large segment of the population, especially those living in poverty, and dependence on natural resources and forestry to drive development, it is highly vulnerable to the harsh impact of climate change (The economics of climate change in Southeast Asia: a regional review, Asian Development Bank 2009) .

Malaysia has taken, perhaps a unique, approach to climate change adaptation over and above other countries in the ASEAN region, possibly due to the economic development beyond its many neighbors (Philip Gass, Hilary Hove, 2011). Often coined as 'adaptation through climate change mitigation', noting that the need for adaptation is unavoidable, but it must be derived in the form of co-benefits from concerted mitigation actions. Nonetheless, climate change adaptation in Malaysia involves action by affected entities, requiring national, state, and local and community level responses. Accordingly, much of Malaysia's adaptation responses come in the form of improved ecosystem management, water resource management, and secured agricultural production - each with a backdrop of doing so to improve productivity, efficiency in resource use, and optimized economic benefit for the State and to individuals. Little attention has been given to autonomous climate change adaptation in practice; rather focus is placed on assessments and planned strategies to achieve the aforementioned. Although adaptation efforts are more enhanced at the national and local level, there are on-going regional efforts within the Southeast Asia region. Funding is the bane of most of the adaptation projects within the region as projects are finances through foreign aids via Global Environment Facility (GEF), USAID and other international donor agencies.

Malaysia has taken the lead with the establishment of Southeast Asia Disaster Prevention Research Institute (SEADPRI) of the National University of Malaysia (UKM) on their own initiative with the supervision of the NSC. The missions of the institute are as follows: ${ }^{4}$

- Conduct holistic research on hazards and disasters at national and regional levels

- Enhance human capital and capacity at national and regional levels, particularly in Southeast Asia

- Support knowledge-based decision making on climatic, geological and technological hazards

The Coral Triangle Initiative on Coral Reefs, fisheries, and Food Security (CTI-CFF) is a USAID funded program is a multilateral partnership of six countries ${ }^{5}$ working together to sustain extraordinary marine and coastal resources by addressing crucial issues such as food security, climate change and marine biodiversity. It is aimed at improving the management of biologically and economically important coastal and; marine resources and associated ecosystems that support livelihoods and economies in the Coral Triangle and assist the six CTI countries in implementing the CTI Regional and National Plans of Action with activities that focus on instituting an ecosystem approach to

\footnotetext{
${ }^{4}$ Available at: http://www.ukm.my/seadpri/?page id=2 last accessed on 19/11/2013

5 Indonesia, Malaysia, Papua New Guinea, Philippines, Solomon Islands and Timor-Leste known as the 'CT6'.
} 
fisheries management, creating marine protected areas, building climate change adaptive capacity and establishing regional platforms to promote cross-country learning and enhance sustainability (Philip Gass, Hilary Hove, 2011) Spanning only $1.6 \%$ of the planet's oceans, the Coral Triangle region comprises $76 \%$ of all known coral species, hosts $37 \%$ of all known coral reef fish species, 53\% of the world's coral reefs, the greatest extent of mangrove forests in the world, and significant commercial fish species. These unparalleled marine and coastal living resources provide significant benefits to the approximately 363 million local people who reside in the Coral Triangle, as a source of food, income and protection from severe weather events, the ongoing health of these ecosystems is critical (Veron et al., 2009). Hyogo Framework for Action (HFA) is a key instrument to facilitate the implementation of disaster risk reduction measures. Adopted during the World Conference on Disaster Reduction held in Kobe, Hyogo, Japan in 2005, HFA provides strategies to build the resilience of nations and communities to disasters, with the goal of achieving substantive reduction of disaster losses by 2015. This is an overall framework for Disaster Risk Reduction (DRR), which can be tailored toward landslide disaster risk reduction. The upgrading of ecosystem is central to disaster management agenda of the HFA. Separately, world policy makers addressing the issue of disasters have noted the need to address climate change concerns within disaster risk reduction strategies, as part of the Hyogo Framework for Action: 2005-2015, which was adopted in Kobe, Japan, in 2005. In order to further solidify Malaysia's commitment towards achieving the strategic goals and priorities of the Hyogo Framework for Action (HFA), the 2011 National Disaster Awareness Day culminated with the Melaka Declaration on Disaster Risk Reduction.

\section{c. Legal Aspects of National Plan for Adaptation (NAPA)}

In assessing the need for ecosystem restoration, there must be a focus on understanding the impacts of climate change on the sector, analyzing the vulnerability of the sector, and identifying adaptation measures. However, any landscape of substantial size, such as a province or watershed, is likely to contain complex systems, both ecologically and socio-economically. People will have different livelihoods that are affected differently by climate change, and they will respond differently. Those impacts may also be unequally distributed due to economic or geographic factors. For example, in the event of a water shortage, people upstream will be better positioned to take the water they need, leaving a smaller share for people downstream. Changes in social and economic conditions may lead to shifts in a sector's activities, change its need for particular resources or the way such resources would be utilized, and, thus, affect its vulnerability. This, in turn, may change the sector's or broader society's adaptation needs (Chinvanno, 2013). These aspects must be taken into account while designing an adaptation related plans.

\section{d. Government initiatives for Ecosystem based Adaptation}

Cross-sectoral approach given to climate change in Malaysia (Pereira, 2013) has been an impetus to varieties of initiatives across all relevant sectors towards combatting climate change.(Robert W. Solar, 2011) In terms of infrastructure, Malaysia has various Flood Mitigation Projects, the most innovative of which is the Stormwater Management and Road Tunnel (SMART) constructed in the Kuala Lumpur city center. The SMART system diverts floodwater via a holding pond, a bypass tunnel, and a 
storage reservoir, preventing spillover into the city during heavy downpours. In addition, local authorities implement the Urban Stormwater Management Manual (MSMA) and Land Use Planning Appraisal for Risk Areas (LUPAr) in the feasibility assessment and execution of physical developments. Finally, the Public Works Department developed the National Slope Master Plan, which enables slope management and disaster risk reduction in incidents of landslides(Chan, 2012; Othman, 2011). Other initiatives in the area of rivers and water resources management include efforts by the Department of Irrigation and Drainage (DID), Malaysia to introduce ecosystem friendly irrigation and the Integrated Flood Forecasting and River Monitoring System (IFFRM). The responsibility for water resources planning and development in Malaysia is shared by various government agencies, such as Ministry of Natural Resources and Environment (NRE), Ministry of Health (MOH), Public Works Department (PWD), Ministry of Housing and Local Government and other water supply companies or privatized (Othman, 2011; Pereira, 2013). The Integrated Flood Forecasting and River Monitoring System (IFFRM) for the Klang Valley is inclusive of a flood modelling system includes in the infrastructure networks which have been completed with 88 new telemetric systems. An Integrated Flood Forecasting and Warning System for the Muda River Basin in Northern Peninsular Malaysia is also being developed simultaneously. This includes developing a radar rainfall analyzer and integrator for Malaysia (RAIM), which feeds information to a real-time flood forecasting system, which is already in place in 13 river basins throughout the country. Upon completion, this project will be extended to the Kelantan, Pahang and Johor river basin. On another note, flood-forecasting models in the Johor, Muar and Batu Pahat river basins are being upgraded to the real-time computerized HEC-HMS model.

In hydrological context, the Department of Irrigation and Drainage (DID) under Ministry of Natural Resources and Environment (NRE), is responsible for the planning, implementing and operation of irrigation, drainage and flood control projects throughout the country. Besides, DID took a new and expanded task of River Basin Management and Coastal Zone, Water Resources Management and Hydrology, Special Projects, Flood Management and Eco-friendly Drainage.

\section{e. Institutions involved in climate change Adaptation in Malaysia}

Climate change and ecosystem-based adaptation takes a center stage in programs and policy of several governmental institutions in Malaysia (Robert W. Solar, 2011). Among the institutions are as follows:

i. $\quad$ Ministry of Natural Resources and Environment (NRE) - Environmental Management and Climate Change Division has had the primary responsibility to develop the 2nd National Communication to the UNFCCC under the stewardship of the Ministry of Natural Resources and Environment (NRE) which chairs both the Project Management Group and the Project Steering Committee, assisted by a secretariat established under the project. The NRE's main course of climate resilience building activities is focused on environmental management/protection, which is the mainstay of Malaysia's approach to adaptation.

ii. $\quad$ National Hydraulic Research Institute of Malaysia (NAHRIM): Regional Water Knowledge Hub for Water and Climate Change Adaptation in Southeast Asia - established by the Government of Malaysia in response to the country's increasing number of water-related challenges, including floods, drought events, deteriorating water quality in rivers and coastal bodies, competing users, erosion, accretion, sedimentation, and not least, the impending anticipated impacts of climate change on water. Operating under the direction of NAHRIM's Research Centre for Water Resources, the regional water knowledge hub for water and climate change adaptation in Southeast Asia has building capacity in areas of water management impacted by climate change due to global warming as its goal.

iii. Malaysian Agricultural Research and Development Institute (MARDI) offers advisory services and consultancy to entrepreneurs and investors in areas relating to agricultural techniques, technology, and management. Efforts related to climate change are focused on 
lowering GHG emissions from agricultural practices, and impact research on production outputs given climate and weather extremes.

iv. $\quad$ Forest Research Institute Malaysia (FIRM) functions include planning and implementing research for the development of the forestry sector and conservation of forest resources and ecosystem functions key to providing assets needed in climate change adaptation and resilience building; obtaining and disseminating research information to enhance forest management and the use of forest products; and establishing joint research and joint forest development with other bodies within and outside Malaysia.

v. The Institute for Environment and Development (LESTARI) was established on 1st October 1994 as a multidisciplinary institute within the structure of Universiti Kebangsaan Malaysia (UKM). LESTARI was also established to serve as a reference center capable of dealing with environment and development issues, assisting government in formulating policies based on research of a holistic and balanced kind. The development function is directed towards enhancing human resource capacity through skill development and training, for both government and private sectors. As a focal point, conducting multidisciplinary and integrated research in balancing trade-offs between environment and development. LESTARI also hosts the Secretariat of MyCLIMATE.

vi. The Malaysian Network for Research on Climate, Environment and Development (MyCLIMATE), providing research support to the National Focal Point for the UNFCCC and the Cabinet Committee on Climate Change in climate change research activities at national, state and local levels. MyCLIMATE is also a network of individuals and organizations from various universities, government agencies and institutions interested in climate change issues to support sustainable development. The Secretariat of MyCLIMATE is hosted by LESTARI, UKM.

vii. Environmental Protection Society, Malaysia (EPSM) is a Non-Profit Environmental Organization. EPSM was founded at a public meeting held at the University of Malaya in Kuala Lumpur on 11 January 1974 by a group of Malaysians concerned about protecting the environment. It is a membership-based national organization, run by an elected Executive Committee on an entirely voluntary, non-profit basis. EPSM objective include the prevention of environmental deterioration as a result of human activities; control human activities that contribute towards deterioration of our environment; initiate measures for the improvement of our environment; and to increase public awareness about the state of our environment. EPSM is also The Climate Action Network (CAN) is a worldwide network of over 700 Non-Governmental Organizations (NGOs) working to promote government and individual action to limit human-induced climate change to ecologically sustainable levels.

\section{Legal Mechanism for Ecosystem restoration and resilience}

In its Second National Communications, released in April 2011, Malaysia identified seven sectors where vulnerability assessments were undertaken, including water resources, agriculture, biodiversity, forestry, coastal and marine resources, energy, and public health. Concerns related to these sectors expressed through both of Malaysia's National Communications include:

Freshwater resources - Concerns expressed relate to supply, floods and erosion (MRRE, 2011). Water resources are already under particular strain in Malaysia because of increasing demand and, in particular, because of irrigation - which accounts for 83 percent of total water usage in the country. Increased periods of drought could further threaten water resources (MSTE, 2000).

Agriculture - The potential impact of climate change on key crops, namely oil palm, rice, rubber and cocoa, are a concern (MRRE, 2011). Flooding due to sea level rise threatens as much as six percent of oil palm production and four percent of rubber production. Temperature rise is also a major concern because of its ability to hamper crop production (MSTE, 2000). 
Forest resources - Mangrove forests are projected to be adversely affected by the temperature rise and dry spells (MRRE, 2011).

Coastal and marine management - Sea level rise, higher sea surface temperatures and increasing intensity, duration and frequency of storms are predicted to occur with negative consequences (MRRE, 2011). Shoreline erosion and loss of mangroves is also presented as a significant threat (MSTE, 2000). Energy - Changes in weather patterns and extreme weather events are projected to have negative impacts on the energy production and development sector, while increases in ambient temperature reduce power generation and put additional stress on transportation infrastructure (MRRE, 2011).

Human health - Climate change will lead to an increase in vector-borne diseases, such as malaria and dengue and water-borne diseases such as diarrhea.

Malaysia launched its National Policy on Climate Change in 2010. Although previous environmental strategies were in place, this policy was the first document that contains a major focus on adaptation. Within it, the government advocates for a balanced approach between mitigation and adaptation (MNRE, 2009). The document contains a number of "Strategic Thrusts" which operate as policy goals and "Key Actions" that are proposals to address climate change and meet these goals. While some of the actions proposed are quite specific, there is not any detailed description of how these actions will be undertaken, or a detailed timeline for their achievement (Philip Gass, Hilary Hove, 2011).

The table below demonstrates Malaysia's Policy instruments relevant to Adaptation to climate change impact.

\begin{tabular}{|c|c|c|c|c|}
\hline $\mathbf{S} / \mathbf{N}$ & Name of policy & $\begin{array}{l}\text { Government } \\
\text { Division } \\
\text { Responsible } \\
\end{array}$ & Status & Sectors of Focus \\
\hline 1. & $\begin{array}{l}\text { Initial National } \\
\text { Communication to } \\
\text { the UNFCCC }\end{array}$ & $\begin{array}{l}\text { Ministry of } \\
\text { Technology } \\
\text { Environment }\end{array}$ & $\begin{array}{l}\text { Submitted August } \\
2000\end{array}$ & Multi Sectoral \\
\hline 2. & $\begin{array}{l}\text { National Policy on } \\
\text { Climate Change }\end{array}$ & $\begin{array}{lr}\text { Ministry of } & \text { Natural } \\
\text { Resources } & \text { and } \\
\text { Environment } & \end{array}$ & Launched in 2000 & Multi sectoral \\
\hline 3. & $\begin{array}{l}\text { National Steering } \\
\text { Committee } \\
\text { Climate Change }\end{array}$ & $\begin{array}{lr}\text { Ministry of } & \text { Natural } \\
\text { Resources } & \text { and } \\
\text { Environment } & \\
\end{array}$ & January 2011 & Multi Sectoral \\
\hline 4. & $\begin{array}{lr}\text { Melaka Declaration } \\
\text { on Disaster Risk } \\
\text { Reduction } \\
\text { Malaysia }\end{array}$ & $\begin{array}{l}\text { National Security } \\
\text { Council (NSC) }\end{array}$ & February 2011 & Multi Sectoral \\
\hline 5. & $\begin{array}{l}\text { Second National } \\
\text { Communication to } \\
\text { the UNFCCC }\end{array}$ & $\begin{array}{lr}\text { Ministry of } & \text { Natural } \\
\text { Resources } & \text { and } \\
\text { Environment } & \end{array}$ & $\begin{array}{l}\text { Submitted April } \\
2011\end{array}$ & Multi Sectoral \\
\hline
\end{tabular}

Strategic Policy direction and reports adaptation needs priorities and plan of action for Malaysia:

Initial National Communication to the UNFCCC: Provides details on national circumstances with respect to climate change, an inventory of GHG emissions, as well as identification of impacts of climate change and potential option for mitigation and adaptation.

National Policy On Climate Change: Presents a framework to meet national objectives of mainstreaming climate change through the management of resources and environmental conservation, 
developing plans and programs to strengthen resilience to impacts of climate change and strengthening institutional and implementation capacity to reduce negative impacts of climate change. It is very focused on integration and mainstreaming of climate actions into all government policy development.

National Steering Committee on Climate Change: To formulate and implement climate change policies including mitigation of greenhouse gas emissions and adaptation to climate change. Members including the Ministries of Natural Resources and Environment, Energy, Water and Communications, Plantation Industries and Commodities, Finance, Education, International Trade and Industry, Agriculture, Foreign Affairs and the Malaysian Meteorological Service.

Second National communication to the UNFCCC: Provides updates on national circumstances and greenhouse gas inventory. Also provides an analysis of mitigation, vulnerability and adaptation activities and an observation of capacity in research and technology. Offers analysis of needs and future plans to address climate change.

Melaka Declaration on Disaster Risk Reduction in Malaysia: Provides recognition for the changing nature of disaster risk in the country due to climate variability and change. Also pledge to strengthen local capacity to integrate climate and disaster risk into local development planning.

\section{a. Terrestrial Ecosystem}

i. Flood control

Floods occur annually in Malaysia, causing damage to property and loss of life. It is useful to distinguish "normal" from "major" flood events. "Normal floods" are seasonal monsoon floods (November to March) whereby waters do not normally exceed the stilt height of traditional Malay houses. Thus, people living in stilt houses in the rural areas are well adapted to normal floods. It is the major floods, which are "unusual" or "extreme" events that render people helpless (Chan, 2012; MALAYSIA COUNTRY REPORT ON DISASTER MANAGEMENT, 2012; Othman, 2011; Robert W. Solar, 2011).

The amount of flood control infrastructures and planning deployed by Malaysia is appreciable. As a developing country, Malaysia's flood mitigation policy can be described as commendable. Since the First Malaysia Plan (1971-1975), the country's expenditure on flood mitigation has increased substantially. From a mere USD 4.56 million in this plan, it has shot up to a massive USD 228.2 million for the Sixth Malaysia Plan (1991-1995), a 50 fold increase over a 20 year period. During the 10th Malaysia Plan, the budget allocated for flood management was USD 1.17 billion, a 256-fold increase.

Legislative framework related to flood control is indirect as there is no flood legislation. Existing legislation is also sector-based and outdated. While there are currently some laws governing the regulation of river use (e.g. the Waters Enactment 1920, the Mining Enactment 1929, the Drainage Works Ordinance 1954, and the Land Conservation Act 1960, and others) and have some bearing on flood mitigation, they are not sufficiently clear or forceful enough as measures for flood mitigation (Chan, 2012).

Flood early-warning system has been adopted by the Drainage and Irrigation Department Malaysia, viz. the Linear Transfer Function Model (LTFM) at Pahang River and the Tank Model at Kelantan River. The two flood forecasting models have been developed and using system consisting of dissemination systems such as automatic warning sirens, the Short Messaging System (SMS), telephone, fax and the Internet. Other flood forecasting mechanisms includes automated telemetric rain gauges and river level recorders (Chan, 2012).

Relocation and rehabilitation of flood victims has been the focus of the Malaysian government with the establishment of the National Flood Disaster Relief and Preparedness Committee (NFDRPC). Its main task is to ensure that assistance and aid are provided to flood victims in an orderly and effective manner from the national level downwards. Its approach is largely reactive to flood disasters. The NFDRPC is activated via a National Flood Disaster Management Mechanism (NFDMM). Members of 
the NFDRPC include Government departments/agencies and social organizations, which provide shelter, rescue and food supplies in case of disaster. The NFDRPC meets at least once a year, normally before the onset of the northeast monsoon, this $s$ in order to focus on the need to get ready before the monsoon arrives (bringing floods with it). Its purpose is to ensure that its machinery will run smoothly. At the national level, the NSC is the secretariat for the NFDRPC, which comprises members from the Ministries of Information, Finance, National Unity and Social development, Transport, the Federal Chief Secretary, the Federal Police Department and the Federal Armed Forces. The NFDRPC coordinates all relief operations from the Malaysian Control Centre in Kuala Lumpur. The NFDMM is basically a mechanism responding to disasters, as its name suggests. As such, its approach towards disaster management/reduction is largely reactive (Chan, 2012).

As noted in Malaysia's Second National Communication to the UNFCCC (NC2), there is the need to review the flood and erosion management plan to accommodate flexible ecosystem based mechanisms as follows (NRE, 2007):

- Review flood management plans and assess integrity of existing structures particularly where failure could result in loss of life.

- Review design standards for flood risk management in all new infrastructure including water control structures, transportation structures and electrical, water and waste amenities to incorporate climate change factors; and

- Complementation of structural approaches with non-structural approaches such as improved rainfall and flood forecasting, disaster warning systems and flood hazard mapping as part of a coordinated disaster prevention and management plan.

- Drainage system improvements to regulate water table depth and prevent floods;

- Further establishment of irrigation facilities (particularly during crop establishment); and

- Cultivar breeding programmes to develop new varieties with high Water Use Efficiency (WUE) traits and drought tolerance.

The absence of a robust ecosystem-based adaptation framework for the management of flood prone area is taking its toll on the environment in Malaysia. Flood legislations are largely focused on disaster risk reduction and risk management. EbA practices if entrenched in future flood legislations can help to reduce the effect of erosion on the livelihoods and save huge relocation and rehabilitation cost that usually follows every major flood disaster.

\section{ii. Forest Management}

The forest ecosystem plays a major role in the global carbon cycle, being carbon sink of the world. Forests are important for water regulation, both on the ground and under the ground, and flood management in river basins. They are also a source of timber products, income for the rural population as well as home to local ethnic peoples. Malaysian forests are very rich in species and are extremely complex ecosystems. In 2000, approximately 56 percent of the total land area of Malaysia was still forested. This included permanent reserve forests (PRFs), state land forests, national parks, as well as wildlife and bird sanctuaries. The remaining comprised of areas of agricultural crops, rubber plantations, oil palm plantations, urbanization or other uses. In 2007, 18.30 million ha, or approximately 55 percent of the total land area of Malaysia was still forested. Table 1.1 presents a breakdown of the total forested area in Malaysia. Malaysia's commitment to maintain 50 percent of its land covered with forests has been reiterated by its Prime Minsters from time to time.

For a number of countries, including Malaysia, the management of forests is a central aspect of ecosystem based adaptation approaches. With adequate relevant legislation to incorporate ecosystembased approaches, the aim of the Malaysia forest policy is to retain and enhance forest cover and other vegetation to the greatest extent possible. 
To maintain forest ecosystems and their carbon storage capacity and to maintain its forest cover, Malaysian government introduced legislation that:

- Requires the completion of national forest inventories, which is almost complete now. It is supported with regional barcode of forests and eco-labeling in order to curb illegal logging.

- Requires mandatory EIAs for converting forests for non-forest use beyond prescribed hectares.

- Prohibition of clearing forests on steep mountains.

- Requires the preparation of sustainable harvest plans.

- Sets high penalties for breaches of certain provisions of the National Forestry Act 1984, especially for illegal logging which carries maximum RM 500,000 thousand fine or and 20 years jail with 1 year mandatory jail.

- Creates a legal obligation to ensure reforestation of logged areas.

- Provides for the use of environmental rehabilitation bonds.

Malaysia has a sizable population of indigenous people who reside in the forest ecosystem. Providing an opportunity for indigenous people (IP) from Myanmar, Cambodia, Indonesia, Malaysia, Philippines, Thailand and Viet Nam was the focus of REDD initiatives on Southeast Asia Indigenous Peoples Regional Consultation on REDD, 9-11 November 2008, Baguio City, Philippines. The regional initiative was to discuss the impact of REDD strategies on right of the Indigenous people (IP). Among the highlights of the forum was:

i. $\quad$ review of framework REDD human rights framework;

ii. issues of land and resource control for indigenous people (IP) and forest governance; and

iii. effective participation of IPs in consultation, capacity building and raising awareness on REDD. (The economics of climate change in Southeast Asia: a regional review, 2009).

REDD has further been enhanced by REDD+, which has an emission mitigation solution and which subsumes REDD, with further novel initiatives, e.g. Forest Carbon Partnership Facility and Forest Investment Programme of the World Bank. But for its success, the REDD+ must be supported by better incentives, especially financial and technological.

\section{iii. Agricultural Ecosystem}

In Malaysia, the projection by (NAHRIM 2006) signifies paddy agricultural yield in Malaysia as a result of positive or negative variation of both rainfall and temperature, and which is expected to continue by the year 2060. Negative impact of climate change on agriculture might be worrisome in Southeast Asian countries due to heavy reliant and central role which the agro-allied sectors play in terms of national income and employment (Koh \& Lovleen, 2011). Some agricultural factors, which affect the adaptability of farmers, are presence of injurious insects, temperature variation, soil fertility loss, cost of input, shortage of rainfall, excessive rainfall among others (Alam, Siwar, Jaafar, Talib, \& Salleh, 2013).

Research on the adaptation options provided by ecological agriculture must take into account context and location specificities such as soil types, crop types, management practices which is capable of helping to adapt to the effect of climate change (Robert W. Solar, 2011). Other factors are: understanding localized research and extension for the development and sharing of 'best practices'; 'Fair Trade' to promote ecological agriculture and small rural farm holders; Knowledge management arrangements for the sharing of information and experiences, transfer of and training in good practices that constitute adaptation in ecological agriculture, including that through extension services. In these areas policy, law and good governance play vital role. (emphasis added) Law can also play role in consolidation of lands, granting lands to landless people, encouraging cooperative and community farming, providing facility to farmers to hold roadside farmers market, which is being practiced my Malaysia, providing soft loan to farmers via village banks supported by the central bank, have well been adopted in India and Bangladesh, and can be emulated by other countries. Likewise, conservation 
and forests and forest resources, all kinds of flora and fauna, can best be managed with participation of forest inhabitants. South Africa is the best example for it. All these help the adaptation in view of global warming, along with alleviating poverty. In view of climate change and its adverse impact on food production, food security is one of the most crucial issues relating to adaptation in the ASEAN countries, especially in Malaysia, Indonesia and Philippines, as a result of increasing reliance on agriculture, fisheries and forestry for livelihood and employment (Koh \& Lovleen, 2011). This is provided under the ASEAN Multi-Sectoral Framework on Climate Change: Agriculture, Fisheries and Forestry towards Food Security (AFCC Framework), which represents a comprehensive and strategic approach to address the impacts of climate change. ${ }^{6}$ Its overall goal is to contribute to food security through sustainable, efficient and effective use of land, forest, water and aquatic resources by minimizing the risks and impacts of and the contributions to climate change. This is further supplemented with the existing ASEAN Integrated Food Security (AIFS) Framework and the Strategic Plan of Action on Food Security in the ASEAN Region (SPA-FS) 2009-2013. ${ }^{7}$ Climate vulnerability in Malaysia has impacted on Agriculture due to the fluctuation in amount of rainfall. Farmers' adaptation practices are based on their own ideas, which are helpful (emphasis added) but are unlikely to stem the trend of reduced crop production. Although there are external support from the government in the form of subsidies and other incentives, farmers were found to be unaware of these supports (Alam et al., 2013). The government provides the following subsidies to farmers:

i. $\quad$ Fertilizer input subsidy of up to $20 \mathrm{~kg}$ per hectare and pesticide worth MYR200 per hectare;

ii. $\quad$ Price Subsidy of up to MYR248.1 per ton;

iii. $\quad$ Rice Production Incentive: Plowing and land preparation incentive of up to MYR100 per hectares and organic fertilizer of up to $100 \mathrm{~kg}$ per hectare; and

iv. Others are Yield Increase Incentive to encourage and reward farmer who produce more and free support for irrigation and water supply.

Fertilizer subsidy support has been established and continued since 1979 while land preparation incentive has been there since 2007. In order for farmers to Adapt to climate change Alam (2012) observed that farmers believed that there should be provision for infrastructural support and leasing systems for moisture deficiency innovation systems.

\section{b. Freshwater Ecosystem}

Freshwater ecosystems in many Southeast Asian and Island countries are under threat due rise in temperature. Rising sea levels, floods, together with storm surges, are likely to result in salination of freshwater lenses. Over times, population growth and sea level rise are likely to lead to increased clearing of water catchments, as settlement and agricultural activities extend further inland (Boer \& Clarke, 2012; Sterrett, 2011).

To maintain water quality, it will be necessary to introduce effective mechanisms for the protection and management of water catchments, including restrictions on clearing and burning in drinking water supply catchments and riparian zones. Relevant legislation concerning the protection of freshwater ecosystems will require review and amendment; where no such provisions are current, various jurisdictions will require preparation of new legislation.

\footnotetext{
${ }^{6}$ ASEAN MULTI-SECTORAL FRAMEWORK ON CLIMATE CHANGE: AGRICULTURE AND FORESTRY TOWARDS FOOD SECURITY available at http://aseanfoodsecurity.asean.org/wp-content/uploads/2011/08/afcc.pdf ${ }^{7}$ ASEAN Integrated Food Security (AIFS) Framework and the Strategic Plan of Action on Food Security in the ASEAN Region (SPA- FS) 2009-2013, Thailand, 1 March 2009, adopted on 1 March 2009
} 


\section{c. Coastal and Marine Ecosystem}

Due to Malaysia's wet equatorial climate regime with frequent heavy rainstorms of high rainfall intensities, landslide disasters are common. In recent decades, landslide disasters in the Klang Valley Region and elsewhere have caused significant loss of life, property and infrastructure damage, environmental destruction and anxiety (T., 2011).

Furthermore, NAHRIM offers specialist consultancy services in project planning and impact assessment in all facets of hydraulic engineering encompassing river and coastal engineering, water resources and water environment. Its main clients include both the public and private sectors in the water-related industry (Othman, 2011). Thus, NAHRIM was highlighted on the urgent need to develop vulnerability and adaptation process and procedures as well as to conduct further research and data collection for a quantified and qualified development of options and decision-making.

\section{i. Fisheries Management and Marine Protected Areas}

Protection of coastal waters and its resources is very important for the maintenance and enhancement of marine ecosystem. Marine Protected Areas - Marine Parks Created under the Fisheries Act 1985 [read with the Establishment of Marine Parks Malaysia (amendment) Order2012] and managed under this Act with the Exclusive Economic Zone 1994 by the Department of Marine Parks - have the major role of maintaining and restoring the marine ecosystems including coral reefs. This has been recognized in the pacific islands and the ASEAN region (Boer \& Clarke, 2012). It has been identified that Global climate change is greatest threat to marine ecosystem including world's coral reefs along with ocean warming, increasing ocean acidification, more intense tropical storms; plus over-fishing, pollution, and sedimentation.

The regional program to conserve marine ecosystem and coral reefs was launched under the CTI-CFF initiative in the Coral Triangle. The goals of the initiative which span along countries are:

i. $\quad$ Priority seascapes designated and effectively managed;

ii. Ecosystem approach to management of fisheries (EAFM) and other marine resources fully applied;

iii. Marine protected areas (MPAs), which are known as marine parks, established and effectively managed;

iv. Climate change adaptation (CCA) measures achieved; and

v. Status of threatened species improving.

Malaysia has recognized the need for integrated planning and management of both land and sea to control and minimize adverse impacts on the marine environment and fisheries management (Visit the official website of the Department of Marine Parks, 2012, created under the Ministry Natural Resources and Environment). In Peninsular Malaysia marine parks were created under the Marine Parks Order 1994. In Sarawak, they were created under the National Park and Reserve Ordinance 1998. In Sabah, they were brought into existence under the Parks Enactment 1984 and Wildlife Conservation Enactment 1997. There is three-tier enforcement, i.e. federal government, state government and local authority. Efforts are being taken to ensure sustainable development and management of coastal areas especially to cope with impacts of climate variability and change including sea level rise. The implementation of the Integrated Shoreline Management Plans (ISMP) by local authorities have already started in selected coastal areas of the country (Robert W. Solar, 2011). 
Malaysia has 9,323 km of coastline and 3,600 km of coral reef area. As stated above, coral reefs in Peninsular Malaysia are mostly protected as Marine Parks under the Fisheries Act (1985) and managed by the Department of Marine Park Malaysia. Fishing is not allowed on the reefs within the Parks (no-take zone), except for non- extractive activities, and reef fisheries are currently nonexistent and unmonitored (Islam, Noh, Yew, \& Noh, 2013). The principal goal in the establishment of MPAs, which have wider restrictive measures, in Peninsular Malaysia is "to protect, conserve and manage in perpetuity, representative marine ecosystems of significance in order that they remain undamaged for future generations and to inculcate public understanding, appreciation and enjoyment of Malaysia's marine heritage".

In 2004, the responsibility of Marine Park management was transferred from Department of Forest Management to the Marine Parks Department Malaysia (MPDM) under the Ministry of Natural Resources and Environment (MNRE). The main reason for this arrangement was to promote sustainable resource management and enhance tourism in the marine parks (Islam et al., 2013). The Department of Forest Management and the MPDM fall under the Federal government's jurisdiction, while the land in the island belongs to the State Government, which decides on all land based development activities. Coordination between state and federal governments is important for the development of adaptive capabilities of the ecosystem in the marine environment.

In Malaysia, main reasons for coral degradation are due to the large number of tourists visiting coral reefs rich coasts for scoop diving, construction of land-based tourism infrastructures, fishing, and pollution through waste disposal and littering (Reef Check Malaysia, 2011, a non-profit organization). The government has undertaken legal protection in order to protect coral reefs from fishing in the MPA areas, including Perhentian Island But legal protection has become less effective due to massive infrastructural development, as there are about 45 resorts/chalets, 19 dive shops, 40 souvenir shops, several restaurants and tea stalls employing a good number of local residents in Perhentian besar and Perhentian kecil. For the small area of Perhentian Island, the number of infrastructures was relatively high compared to other marine parks in the east coast of Peninsular Malaysia (Islam et al., 2013). The other reason for not taking proper care of Perhentian is the conflict of jurisdiction between the Federal government and the State government.

\section{Environmental Assessment and strategic planning}

\section{a. Environmental Impact Assessment}

Environmental impact assessment (EIA) is an important tool for assessing and managing probable impacts of development on the ecosystem resilience. To minimize the negative impacts of climate change on environment and people, it is important to integrate consideration of ecosystem resilience into the Malaysia EIA made under the Environmental Quality Act 1974 and the Environmental Quality (Prescribed Activities) (Environment Impact Assessment) Order 1987 according to the EIA Guidelines. In order to provide an accurate view of the landscape in the long-term, which is the timescale of climate change, in supporting adaptation planning, additional vulnerability and adaptation assessment is undertaken taking into consideration socioeconomic factors as well as interactions amongst sectors. In Malaysia, EIA is made mandatory on activities, which are deemed to have adverse effect on the environment under the Environmental Quality Act 1974 to be undertaken by the Department of Environment. Mitigative measures, if necessary, are required prior the EIA with respect proposed project approved. EIA approvals are generally with certain necessary conditions to be complied with by the proponent. It is suggested that adaptive capacity of the ecosystem of any given project area should be a necessary consideration in project implementation projects. A robust EIA 
together with adaptation assessment mechanisms can be used to prevent development around wetlands: declaring more wetlands as Natural Protected Areas as well as extending existing ones to cover future inundatable lands, establish wetland friendly land-uses around current wetlands through the different zoning schemes, require buffer areas as part of the mitigation measures in EIA processes. To manage the impacts of development on ecosystem resilience, it is recommended that each country adopt EIA regulations requiring consideration of the extent to which a proposed development is likely to increase vulnerability to the predicted impacts of climate change. Development of environmental guidelines, for consideration of the impact of proposed developments on ecosystem resilience, will help to promote robust assessment and approval processes (Boer \& Clarke, 2012).

\section{b. Strategic Planning and disaster management}

Adaptation to climate change and disaster risk reduction share common features - they are not sectors in themselves but must be implemented through the policies of other sectors, in particular, those of agriculture, water resources, health, land use, environment, finance and planning (Adaptation to Climate Change by Reducing Disaster Risks $\square$ : Country Practices and Lessons, 2009). There are also linkages with other policies, most notably poverty eradication and planning for sustainable development, and education and science.

The law of climate change adaptation in Malaysia cannot be viewed in complete isolation from disaster risk reduction or vice versa. As experience with both disaster risk reduction and climate change adaptation grows, there is increasing recognition in the ASEAN region and the Pacific that these two fields share a common focus, i.e. reducing the vulnerability of communities and contributing to sustainable development. Given the high magnitude of climate-related risks in the ASEAN region, disaster risk reduction and climate change adaptation have been the one of the major policy goals of the Malaysia government.In Malaysia, the National Security Council (NSC) is the principal policymaking and coordinating body for disaster management. The NSC coordinates and plans all activities related to disaster preparedness, prevention, response/relief operations and recovery/rehabilitation.

The National Security Council Directive No. 20 (NSC No. 20): The Policy and Mechanism for National Disaster and Relief Management is the main guideline for disaster management in Malaysia. The Directive prescribes the mechanism for the management of disasters, including the responsibilities and functions of related agencies under an integrated emergency management system. This is achieved through the establishment of the Disaster Management and Relief Committee at three different levels (Federal, State and District levels) pending the severity of the disaster. The Directive is supported by other Standard Operating Procedures which outline the mechanism as well as roles and responsibilities of various agencies for specific disasters, i.e. flood, open burning, forest fire, haze, industrial disasters, etc. (3rd AIPA CAUCUS REPORT, 2011, MALAYSIA COUNTRY REPORT ON DISASTER MANAGEMENT, 2012)

\section{c. Protection of the rights of indigenous people}

Adaptation is at the core of livelihood of the local and indigenous people globally, as it tends to affect their sustenance and reliance on the ecosystem for their basic needs. Through the International Indigenous Peoples' Forum on Climate Change (IIPFCC), indigenous peoples seek recognition of 
their contribution to climate change adaptation issues, and respect for their right to be actively engaged and to participation in decision-making pertaining to climate change policy (Francesco, Martone. , Jen, 2012). Demands on climate finance, as stated through global collective statements and declarations, relate to ensuring that indigenous peoples do not become more vulnerable in the execution and implementation of climate change projects, and ensuring their full and effective participation of in global and national efforts to mitigate and adapt to climate change.

Malaysia's population of nearly 24 million $^{8}$ comprise an indigenous population of about 65 per cent of which Malays are the majority. The immigrant population, the Chinese comprise 26 per cent and Indians 7.7 per cent. In Peninsular Malaysia, the aboriginal people (Orang Asli) form about 0.5 per cent of the population ${ }^{9}$ whereas the indigenous groups in Sarawak comprise about 69.1 percent, and in Sabah, about 60.7 percent of the respective states' population. ${ }^{10}$

Malaysia is a signatory to the UN Declaration on the Rights of Indigenous Peoples (UNDRIP), which requires states to consult and cooperate in good faith with indigenous peoples through their own representative institutions in order to obtain their free prior and informed consent (FPIC) before adopting and implementing legislative and administrative measures that may affect them. Also in 1994, Malaysia ratified the Convention on Biological Diversity (CBD) of which article 8(j) requires states to "respect, preserve and maintain knowledge, innovations and practices of indigenous and local communities embodying traditional lifestyles relevant for the conservation and sustainable use of biological diversity". The rights of aborigines is protected under the Aboriginal Peoples Act 1954, which provides for the declaration of any area predominantly or exclusively inhabited by aborigines to be an aboriginal area or aboriginal reserves. ${ }^{11}$

However, in the implementation of climate change policies, the indigenous people have been educated on how to adjust to the developments around their habitat including the right of the people to egress and ingress. The downside of this policy approach is the social acceptance of the idea that some settlements may need to move several times in people's lifetime.

\section{Financing mechanism for ecosystem adaptation}

\section{a. Legislated funding mechanism}

This section concerns examination of appropriate funding mechanisms to promote incorporation of ecosystem-based adaptation mechanisms into the relevant legislation. These climate finance is needed to help vulnerable communities adapt to, and the adverse effects of a changing climate. The climate funding is a crucial issue for countries in South Asia, both in terms of how international sources of finance are governed, as well as the capacity of national institutions to make best use of climate finance when it is available (Regional Workshop on Options for an Innovative Climate Finance Regime for South Asia, 2013).

\footnotetext{
${ }^{8}$ Population Distribution and Basic Demographic Characteristics Report: Population and Housing Census 2000. htpp://www.statistics.gov.my/English/census/pressdemo.htm

${ }^{9}$ Colin Nicholas puts the figure at 147,412 individuals in 2003. See Colin Nicholas. Centre For Orang Asli Concerns, http://www.coac.org.my (accessed on 2 November 2009).

${ }^{10}$ Malaysia, Department of Statistics, State/District Data Bank 2005.

${ }^{11}$ Section 6 of the Aboriginal Peoples Act 1954.
} 
There is growing policy interest in the costs of adaptation. This has a lot to do with the role of adaptation in the negotiations for a post-2012 climate agreement. ${ }^{12}$ A commitment by developed countries to finance adaptation in developing countries is a key element of the new global climate change regime that is currently being negotiated; and perhaps negotiators would like to know what the magnitude of this transfer might be. Independently, many governments are also beginning to worry what adaptation will mean for their own countries and their own budgets (Fankhauser, 2009).

In Malaysia, finance and incentives for climate change adaptation is a key policy and governance action elements of the National Policy on Climate Change (Ministry of Natural Resources and Environment, NRE, 2011). Although, Malaysia is the richest in the ASEAN region, international involvement in climate change adaptation funding is a viable source for initiative as obligated under international climate instruments. Funding by donors is steered through the Environmental and Climate Change Management Division of NRE. This includes bilateral and multilateral cooperation, capacity building activities, information sharing and networking at both national and international levels. Noting the aforementioned, supporting Development Partners are the United Nations Development Program (UNDP) with funding from the Global Environment Facility (GEF); the World Bank; the Asian Development Bank; the European Communities - Association for Southeast Asian Nations ASEAN Energy Facility (EAEF); the DANIDA and Japan International Cooperation Agency (JICA), New Energy and Industrial Technology Development Organization of Ministry of Energy, Trade and Industry, Japan (Othman, 2011).

The National Adaptation Programmes of Action (NAPA) has been prepared under the auspices of the 1992 UN Framework Convention on Climate Change, and financed through the Global Environment Facility. In 2007, the Secretariat of the UNFCCC commissioned five sector studies to get a better handle of investment needs for adaptation both globally and in developing countries (UNFCCC 2007).

Under the GEF, the UNFCCC estimate is an important step forward. Although incomplete, the study adds considerably more sector detail to understanding of costs. In its GEF report to the UNFCCC presented at COP 19, adaptation has been the focal point of projects and planning funded by GEF. ${ }^{13}$ Funding under the Least Developed Countries Fund (LDCF) within the reporting period amounting to 271.4 million US dollars were approved for 41 projects plus 1.06 billion US dollars in external cofinancing leveraged. Additionally, under the Special Climate Change Fund (SCCF) Adaptation Program: the GEF provided 39.1 million US dollars for nine projects and programs, which in turn leveraged 218.2 million US dollars in co-financing.

Malaysia Since joining the GEF, has received GEF grants totaling USD 63 Million that leveraged USD 179 Million in co-financing resources for 18 national projects, 24 regional and global projects. These include eight projects in biodiversity, eight in climate change, and two in multi-focal areas. ${ }^{14}$

\footnotetext{
${ }^{12}$ The 2010:COP16 of the UNFCCC outlined the adaptation framework, known as Cancun Adaptation Framework, which states: The Cancun Adaptation Framework (CAF) was established at COP16, in Cancun. Activities under the CAF relate to the following five clusters: Implementation, including a process to enable LDC Parties to formulate and implement national adaptation plans (NAPs), and a work programme to consider approaches to address loss and damage; support; institutions, including the establishment of an Adaptation Committee at a global level, as well as regional and national level arrangements; principles; and stakeholder engagement. There is already an Adaptation Fund under the Kyoto Protocol, the Green Climate Fund under the UNFCCC, Special Climate Change Fund and Least Developed Countries Fund managed by the Global Environmental Facilities (GEF). See infra.

${ }^{13}$ Available at: www.thegef.org/gef (accessed on 12 January 2014).

${ }^{14}$ Available at: http://www.thegef.org/gef/sites/thegef.org/files/publication/Malaysia\%20-\%20Fact\%20Sheet\%20\%20Feb2013_EN.pdf (accessed on 14 January 2014).
} 
Climate adaptation financing was at the fore of COP 19 negotiations in Warsaw 2013, where Malaysia speaking for the G77/CHINA alongside India, Egypt and Kenya, while expressing concern for lactk of funding for adaptation called for a legislated financing of adaptation under the NAPs at the country level and strengthening existing adaptation institutions around the world (IISD, 2013).

\section{b. Ecosystem-based mechanism at Local level}

Community-based management of ecosystem combines traditional and local knowledge, scientifically sound monitoring methods and responsive decision-making processes to provides a strong foundation for improving resilience of ecosystems and responding to new challenges, including the impacts of climate change (Boer \& Clarke, 2012).

Despite the robust climate change adaptation initiatives at the regional and national levels, it is of utmost priority the needs to further identify public safety vulnerabilities, delivery processes at the local level. In Malaysia local participation has been delivered through localized information related to climate hazard risks and associated vulnerability mapping; research on the development (needed parameters), and deliver of vulnerability assessments (including facilitation knowledge) by local level researchers/ facilitators; and an understanding of local government (top-down) process and procedures for cross sector and vertical collaboration for effective risk reduction responses.

In addition, raising awareness and sensitization efforts for local government actors, to community level participants will be required to ensure that assessments are contextualized, understood to include ecosystem services and eventually moved towards the acceptance of a Standard Operational Procedure (SOP)(Robert W. Solar, 2011) .

\section{Implementation, Compliance and Enforcement}

Implementation, compliance and enforcement of environmental legislations are distinct aspects to be understood differently (Boer \& Clarke, 2012). In climate change, adaptation concerns policy formulation functions are channeled through international instruments such as the UNFCCC, United Nation Convention on Biodiversity CBD and related decisions reached at the COPs.

In Malaysia, climate change policy concerns are directed through various sectors such as: energy, irrigation, natural resources, land-use planning, solid waste among others and facilitated by the National Steering Committee on Climate Change (NSCCC) under the leadership of the Secretary General of the Ministry of Natural Resources and the Environment. The implementation of climate change policy including adaptation is saddled with the National Policy on Climate Change and the National Green Technology Policy which is chaired by the Prime Minister of Malaysia (Robert W. Solar, 2011). Adaptation Working Committee is one of the several committees of the council. Among the functions of the council is to ensure implementation and compliance with international agreements on climate change, which Malaysia has become a party.

Each sector or ministry enforces compliance with climate change and adaptation policies determined by the council. Relevant government environmental departments charged with enforcement of regulations aimed at achieving the overall objective of reducing the impact of climate change and adaptation in the country. 
However, there is a pressing need for capacity building programme to ensure adequate focus on adaptation to climate change through the instrumentality of natural ecosystem. The role of the traditional resource owners such as local community particularly the aborigines in this regard are essential to enforcement of adaptation policies in the country. Specific legislation for empowering the local people to enforce adaptation measures can help to strengthen resilience to the impact of climate change.

\section{Conclusion}

In view of the adverse impacts of climate change on people and resources for their survival, Malaysia has law and policy to augment mitigation and adaptation supported with instilling the element of necessity preventing wastage with respect to consumption of natural resources, especially water. Among them, boosting conservation of energy, maximizing the use of energy efficient equipments, minimizing use of wood by the village households, conserving forests in general and wetlands in specific, enlarging the tapping of REDD+, shifting to genetically modified crops which can survive in adverse weather conditions, learning from customary adaptation techniques, alleviating use of air conditioners, making people to be used to water rationing in crisis situations, maximizing the public transport, increasing the use of PV cells for fulfilling energy needs, harnessing rainwater for domestic use and irrigation, and increasing constructive peoples' participation in coastal management are notable. However, due to lack of enough technological and financial resources to encourage adaptation, the pace of adaptation is not encouraging. There is plenty of scope for Malaysia to learn from some developing economies like India and China, where adaptation is bring real relief to the people suffering from adverse weather conditions. It is well accepted that mitigation, disaster management have to go along with adaptation. The track record Malaysia with respect to disaster management, especially land slides, is quite good. The country has undertaken the task to review all landslide prone areas and to take necessary preventive measures. (New Straits Times, 1 May 2014). So far mitigation is concern, the country is doing its best. But the government should work hard to maximize the renewable sources of power generation in order to achieve the target set to be achieved by 2020 . It will be possible only if the country uses this energy source for rural electrification on cooperative basis.

The following are some suggestions for consideration, based on the review of the current scientific literatures on adaptation strategies, Malaysian Second National Communication to the UNFCCC, National Adaptation Plans, adaptation made by relevant departments:

1. There is a need for a detailed review of existing environmental policies both at national and state levels to include natural resources management towards adaptation and ecosystem resilience to the impacts of climate change. There must be close cooperation between state and federal authorities on this matter. They should work together to make best use of available resources. They should together work for increasing resources and capacity building.

2. There is a need to provide robust adaptation mechanisms for consideration in the environmental impact assessment and social impact assessment to include specific provision on 
ecosystem-based adaptation assessment at all levels of government including the community levels.

3. The Adaptation Working Committee under the National Policy on Climate Change should work to promote community-level integration in adaptation planning with national laws. This will strengthen and secure adaptive capacity of the ecosystem.

4. Malaysian universities should engage more with the regional research networking efforts among universities in Asia. Example: Asian University Network of Environment and Disaster Management (AUEDM). This will enable cross-fertilization of ideas in the area of ecosystembased adaptation in the region. It is important to note that networking is most effective when its purpose is clear, its members are committed and its mechanism and activities are sustainable.

5. Help of NGOs and social activist should be enhanced.

6. A regulatory approach to tourism activities and ecosystem deterioration in the designated marine protected area in Malaysia to protect and conserve biodiversity, which will also help to build, is warranted.

7. Climate adaptation funding should be enhanced through private initiative to support the inadequate finance mechanism sourced from international and multilateral institutions.

8. Customary mechanism for implementation and enforcement of adaptation measures should be encouraged in specific legislations at local and community level to include ecosystem based adaptation practices. They can further be enhanced, as coupling adaptive improvements in infrastructures with effort to improve ecosystem resilience will make the communities resilient.

9. There is need to both top-down and bottom-up assessments conducted from time to time so that necessary changes are made in order to make the risk minimal.

These suggestions are in line with the observations made by the Working Group II of the $5^{\text {th }}$ Assessment Report on Climate Change 2014: Impacts, Adaptation and Vulnerability in chapters 14, 15. $16 .^{15}$

\footnotetext{
${ }^{15}$ See at: www.ipcc.ch/report/ar5/wg2
} 


\section{References:}

3rd AIPA CAUCUS REPORT. (2011) (pp. 1-40). Philippines. Retrieved from http://www.aipasecretariat.org/wp-content/uploads/2011/07/5.third_.caucus.report.pdf

A. Colls, N. A. and N. I. (2009). Ecosystem-based Adaptation $\square$ : A natural response to climate change (p. 19). Gland, Switzerland.

Adaptation to Climate Change by Reducing Disaster Risks $\square$ : Country Practices and Lessons. (2009). International Strategy for Disaster Reduction.

Adhikary, S., Ando, M., Anokhin, Y., \& Cruz, R. V. (n.d.). MURARI LAL (INDIA), HIDEO HARASAWA (JAPAN), AND DANIEL MURDIYARSO (INDONESIA).

Alam, M. M., Siwar, C., Jaafar, A. H., Talib, B., \& Salleh, K. B. O. (2013). Agricultural Vulnerability and Adaptation to Climatic Changes in Malaysia: Review on Paddy Sector. Current World Environment, 8(1), 1-12.

Annex-5 Decision Document on: Climate Change Adaptation Working Group Report. (2012) (pp. 2224).

Ansari, Abdul Haseeb and Umar A. Oseni 2012. Wetlands and Global Warming: impacts, Adaptation and Mitigation (Developing Countries' Perspective). pp. 112-161, Serials Publications, New Delhi.

Baker-jones, M., Burton, D., Bell, J., \& Chang Seng, D. (2013). Climate change adaptation Guided by the Law. Fiji.

Boer, B., \& Clarke, P. (2012). Legal Frameworks for Ecosystem-Based Adaptation to Climate Change in the Pacific Islands (p. 56). Apia, Samoa.

Brooks, N. (2003). Vulnerability, risk and adaptation: A conceptual framework. Tyndall Centre for Climate Change Research Working Paper, 38, 1-16.

Chan, N. W. (2012). Impacts of Disasters and Disasters risk Management in Malaysia: The case of Floods. In Sawada (Ed.), Economic and Welfare Impacts of Disasters in East Asia and Policy Responses. (pp. 497-545). Jakarta: ERIA Research project Report 2011-8.

Chinvanno, S. (2013). A holistic approach to climate change vulnerability and adaptation assessment $\square$ : Pilot study in Thailand REGIONAL CLIMATE CHANGE. Bangkok. Retrieved from www.asiapacificadapt.net

CIA. (2013). The World Factbook. Retrieved from https://www.cia.gov/library/publications/theworld-factbook/geos/my.html

Evan, Halper, "Coping with global warming", The Star, 19 May 2014.

Fankhauser, S. (2009). The costs of adaptation. London. 
Francesco, Martone. , Jen, R. (2012). INDIGENOUS PEOPLES AND THE GREEN CLIMATE FUND A technical briefing for Indigenous Peoples, policymakers and support. Forest Peoples Programme and JOAS.

Ferrario, Fillippo, Michael W. Beck, Curt D. Storlazz, Fiorenza Michell, Christine C. Sheppard and Lara Airoldi (2014). "The effectiveness of coral reefs for coastal hazard risk reduction and adaptation", nature communication, 13 May 2014.

Gatti, R. C. (n.d.). Building Resilience to Climate Change Building Resilience to Climate Change Ecosystem-based adaptation and lessons from the field.

Huq, N., Renaud, F., \& Sebesvari, Z. (n.d.). ECOSYSTEM BASED ADAPTATION ( EbA ) TO CLIMATE CHANGE - INTEGRATING ACTIONS TO SUSTAINABLE ADAPTATION.

IISD. (2013). Earth Negotiations Bulletin. IISD, 12(November), 1-4. Retrieved from http://www.iisd.ca/climate/cop19/enb/

Islam, G. M. N., Noh, K. M., Yew, T. S., \& Noh, A. F. M. (2013). Assessing Environmental Damage to Marine Protected Area: A Case of Perhentian Marine Park in Malaysia. Journal of Agricultural Science, 5(8), 132-141. doi:10.5539/jas.v5n8p132

Klein, R., Huq, S., Denton, F., \& Downing, T. (2007). Inter-relationships between adaptation and mitigation, 745-777. Retrieved from http://su.diva-portal.org/smash/record.jsf?pid=diva2:180448

Koh, K. L., \& Lovleen, B. (2011). GOVERNANCE ON ADAPTATION TO CLIMATE CHANGE IN THE ASEAN REGION Governance on Adaptation to Climate Change in the Asean Region. Carbon and Climate Law Review, 82-90.

Lim, B., Spanger-siegfried, E., Burton, I., Malone, E. L., \& Huq, S. (n.d.). A DAPTATION P OLICY F RAMEWORKS FOR C LIMATE C HANGE $\square$ : D EVELOPING S TRATEGIES , P OLICIES AND M EASURES.

Maguel A. Altieri, Parviz Koohafkan and Clara Nicolas (2014). Strengthening resilience of modern farming systems: A key prerequsite for sustaianable agricutural production in an era of climate change. TWN Briefing Paper 70, January 2014. See at: www.twn.my

MALAYSIA COUNTRY REPORT ON DISASTER MANAGEMENT. (2012).

Nelson, V., Lamboll, R., \& Arendse, A. (2008). Climate change adaptation, adaptive capacity and development discussion paper. DSA-DFID policy forum 2008.

NRE. (2007). Malaysia: Second National communication to the UNFCCC. PUTRAJAYA, MALAYSIA. Retrieved from nc2.nre.gov.my

Othman, S. B. (2011). Adaptation to Climate Change and Reducing Natural Disaster Risk $\square$ : A Study on Country Practices and Lesson between Malaysia and Japan.

Pereira, J. J. (2013). Effective Networking Strategies for Adaptation Governance - A Perspective from Malaysia. Kobe , Japan: SEADPRI-UKM. 
Pérez, A. A., Fernández, B. H., \& Gatti, R. C. (2010). Building Resilience to Climate Change: Ecosystem-based adaptation and lessons from the field. IUCN.

Philip Gass, Hilary Hove, J.-E. P. (2011). Review of Current and Planned Adaptation Action $\square$ : East and Southeast Asia Action $\square$ : East and Southeast. Adaptation Partnership. Retrieved from www.adaptationpartnership.org/

Pramova, E., Locatelli, B., Brockhaus, M., \& Fohlmeister, S. (2012). Ecosystem services in the National Adaptation Programmes of Action. Climate Policy, 12(4), 393-409. doi:10.1080/14693062.2011.647848

Regional Workshop on Options for an Innovative Climate Finance Regime for South Asia. (2013). Bangkok. Retrieved from http://www.asiapacificadapt.net/apan-cansa-20130819

Ingham, Richard. (2014). "Natural buffers for coastlines", The Star, 19 May 2014.

Roach, John, NBC News, 14 August 2013 at 6:59 PM ET.

Robert W. Solar. (2011). Scoping Assessment on Climate Change Adaptation in Malaysia. 2001.

Ruhizal Roosli, Phil O'Keefe, M. A. O. M. (2013). Evolution of Disaster Planning and Housing in Malaysia $\square$ : A Reviews, 21(7), 945-959. doi:10.5829/idosi.wasj.2013.21.7.2159

Sahraie, M. (2011). SUSTAINABLE DEVELOPMENT LAW ON CLIMATE CHANGE RECOGNIZING OR PRO-ACTIVELY.

Sterrett, C. (2011). Review of Climate Change Adaptation Practices in South Asia, (November), 1100.

T., P. (2011). "Slope Failure Hazards: a Spatial and Temporal Study of the Klang Valley Region, Peninsular Malaysia.” University of Malaya , Kuala Lumpur.

The economics of climate change in Southeast Asia: a regional review. (2009) (pp. 1-225).

UNDP. (2013). International Human Development Indicators - UNDP. Retrieved from http://hdrstats.undp.org/en/countries/profiles/MYS.html

Veron, J. E. N., Devantier, L. M., Turak, E., Green, A. L., Kininmonth, S., Stafford-Smith, M., \& Peterson, N. (2009). Delineating the coral triangle. Galaxea, Journal of Coral Reef Studies, 11(2), 91-100.

Wertz-Kanounnikoff, S., Locatelli, B., Wunder, S., \& Brockhaus, M. (2011). Ecosystem-based adaptation to climate change: What scope for payments for environmental services? Climate and Development, 3(2), 143-158. doi:10.1080/17565529.2011.582277 